Annals of Warsaw University of Life Sciences - SGGW

Land Reclamation No 46 (1), 2014: 43-55

(Ann. Warsaw Univ. of Life Sci. - SGGW, Land Reclam. 46 (1), 2014)

\title{
Using hydrodynamic modelling to assess the impact of the development on hydrogeological conditions in a polygenic river valley marginal zone
}

\author{
FILIP BUJAKOWSKI $^{1}$, TOMASZ FALKOWSKI ${ }^{1}$, GRZEGORZ WIERZBICKI ${ }^{1}$, \\ KORNELIA ŻUKOWSKA ${ }^{2}$ \\ ${ }^{1}$ Department of Geotechnical Engineering, Warsaw University of Life Sciences - SGGW \\ ${ }^{2}$ Institute of Hydrogeology and Engineering Geology, University of Warsaw
}

\begin{abstract}
Using hydrodynamic modelling to assess the impact of the development on hydrogeological conditions in a polygenic river valley marginal zone. The study area is located in the southern part of the Warsaw city agglomeration, adjacent to the Chojnowski Landscape Park. The study area is situated in the boundary zone between: (1) the bottom of the river valley reach with peat cover and (2) the Pleistocene glaciofluvial plain on its lower level. The main aim of the study is the analysis of the investment impact on hydrogeological conditions. During the pre-construction site works on the bottom of the valley it was an earthwork constructed in order to extend the zone of the buildings in the valley area. The research method consists of field works (geological drillings, piezometers constructions and observations, geodetic measurements), as well as laboratory works (sieve analysis) and hydrodynamic modelling (Visual MODFLOW, version 2009.1). The hydrogeological model performed in the study seems to became a base for the concept of the restoration of groundwater conditions.
\end{abstract}

Key words: peat, wetlands, draining, hydrogeological modelling, hydrogeological condition

\section{INTRODUCTION}

A development of housing estates observed in Poland since the end of the 1990 s encourages investors to reclaim even areas with difficult engineer-geological conditions, such as valley slopes or floodplains. Residential investment is currently being conducted also in areas with shallow groundwater table. These are mainly the plains of glaciofluvial and ice-dam lakes deposition as well as polygenic reaches of river valleys. The presence of valuable hydrogenic habitats, that often contains unique flora and fauna species communities is very often the characteristic feature of such zones (Okruszko et al. 1996). Moreover wetlands cover $4.2 \%$ of the Polish area and have a great importance in the retention of the fresh water. Retention capacity of the peatlands in Poland is estimated at 34 billion $\mathrm{m}^{3}$ (Churski 1993). Therefore development of such zones apart from technical problems is often associated with the need to resolve conflicts between the investment requirements and the environmental protection.

The study area is located in the southern part of the Warsaw city agglomeration, adjacent to the Chojnowski Landscape Park (Fig. 1). This is the boundary zone of the bottom of the polygenic river valley (Mała River) that is covered with peat (Brandyk 1990) and the Pleistocene glaciofluvial plain on its lower level. The environment in the bottom of the Mała River valley (Fig. 1) was seriously changed ca. five years ago by extension 


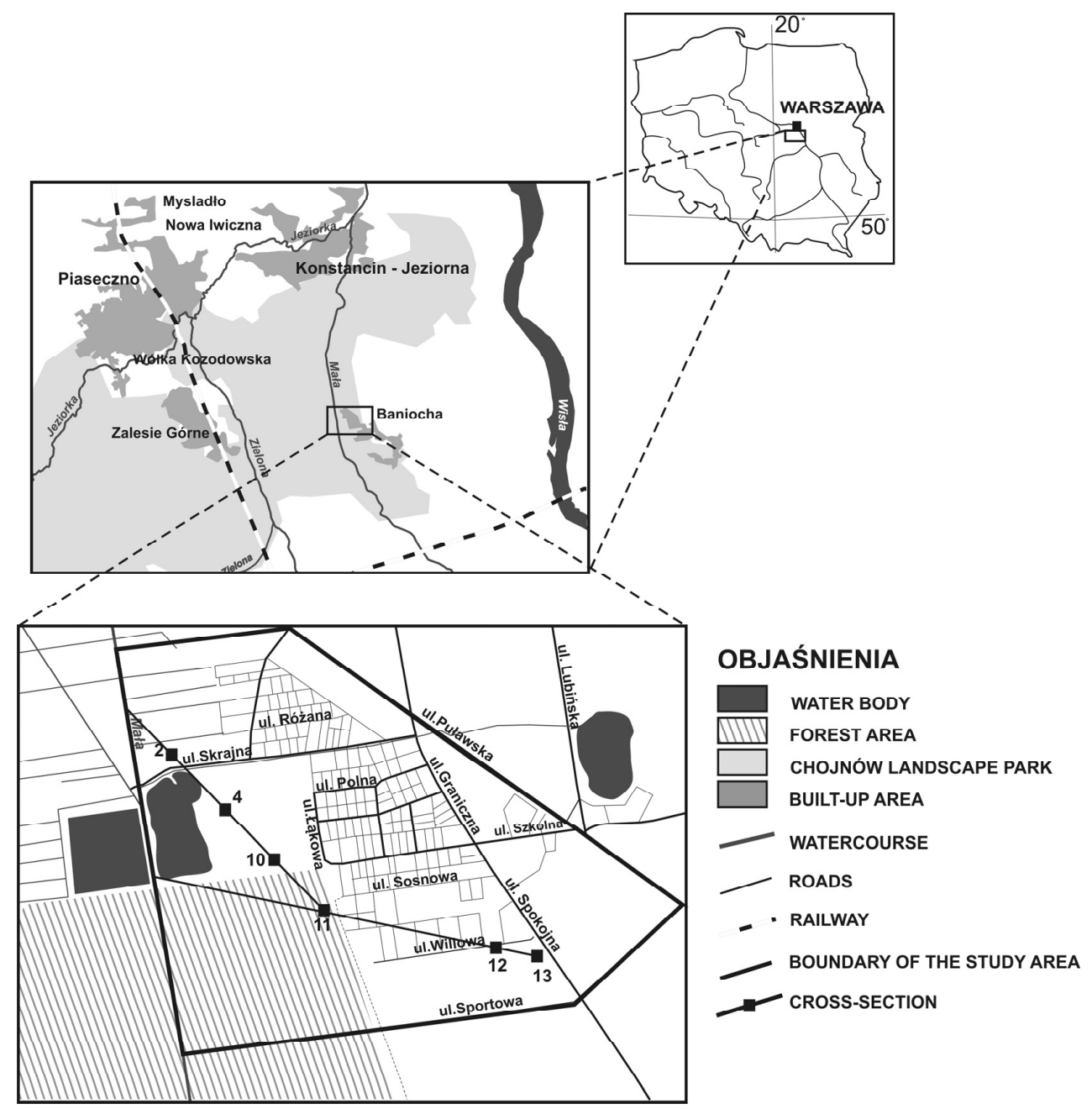

FIGURE 1. Location of the study area

of the investment zone. The draining system was destroyed. The peat cover was excavated and replaced by an earthwork. The earthwork is built with different kind of soils: sand, silt, clay, gravels, and debris of anthropogenic origin. The change of hydrogeological conditions probably induced increase of groundwater table and seasonal flooding of adjacent building located easterly from the study area.
The main aim of the study is the analysis of the investments impact on the polygenic river valley hydrogeological conditions as well as determining the suitability of the numerical, hydrodynamic groundwater flow model for a concept of groundwater condition restoration of areas subjected to a human impact. The research was realized within spring and summer of 2012. 


\section{MATERIAL AND METHODS}

The research was executed in two stages. The first one was to determine geological and hydrogeological conditions of the model. Geological mapping was carried out to recognize a detailed geological setting of the study area. Geological mapping consists of 13 drillings with the depth of 2.2 up to $8.0 \mathrm{~m}$ and some excavations. A granulometric analysis (sieve) of the soils composing the described layers was also prepared. The basic materials for the construction of the numerical model of groundwater flow conditions was the monitoring of the water level in seven piezometers, in the Mała River channels and in the ponds. The results of groundwater and surface water table monitoring as well as informations about its seasonal dynamics obtained from the people living in neighbourhood were the basis for the model calibration.

Topographic measurements of wells in private estates (seven piezometers), as well as water level in the channel of Mała River, were performed using the conventional geodetic equipment and GPS-RTK. As a tool for the modelling studies (mathematical modelling) was used Visual MODFLOW (version 2009.1) from Waterloo Hydrogeologic Inc. The model was integrated with GIS database which had been created in ArcGIS (version 10) from ESRI Inc.

\section{RESULTS}

\section{Outline of the geological and hydrogeological conditions}

The oldest sediments identified in the study area are clays and silty clays. According to Sarnacka (1974), the age of these deposits is dated back to the maximal stadial of Middle Polish Glaciation [Odra Glaciation by Lindner (1988)] marked as layer 10, on Figure 2. Above clays there are the series of fluvial facies

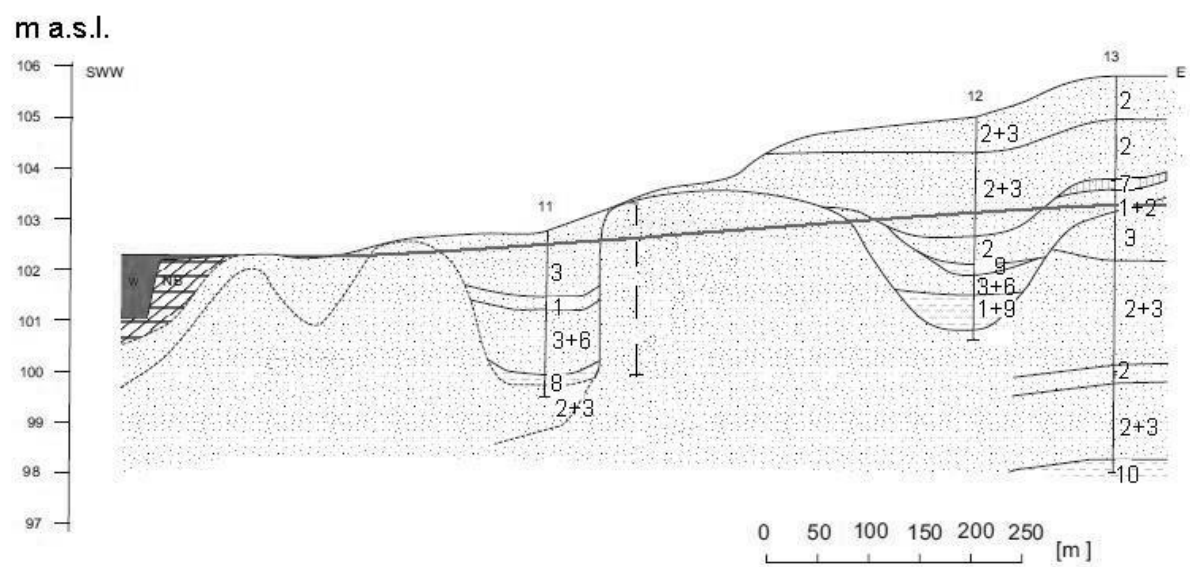

FIGURE 2. Lithological cross-section of the analyzed zone; location on Figure 1; explanations: 1, 2, 3, 4, 5 - sand, respectively: silty, fine, medium, heterogranular, coarse, 6 - gravel, 7 - sandy clay, 8 - silt, 9 - sandy silt, 10 - loam, 11 - peat 


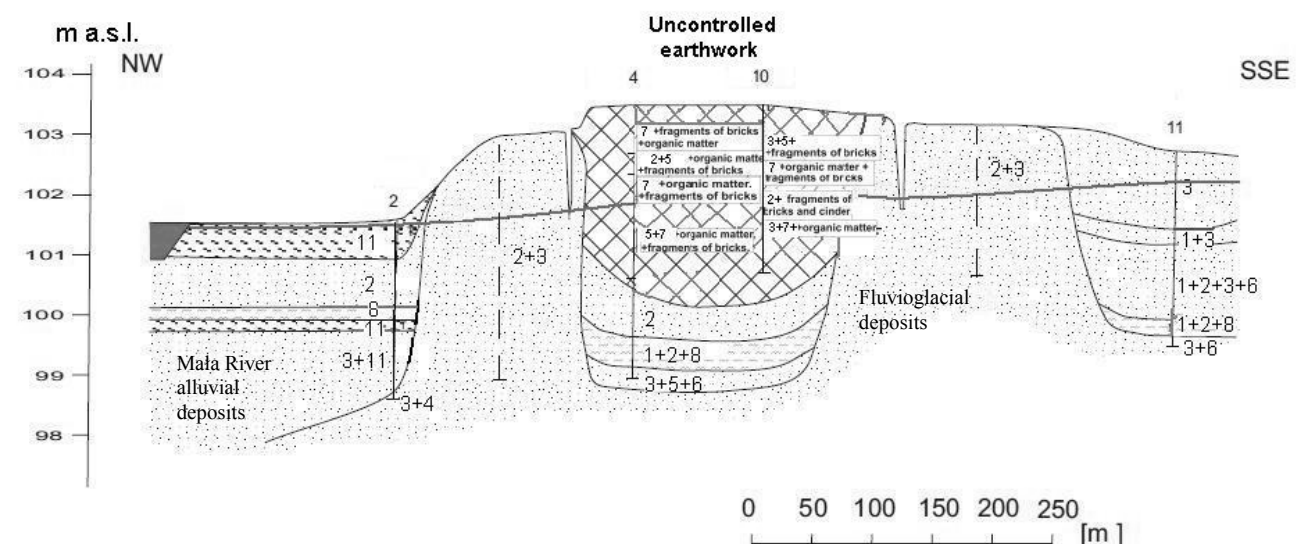

FIGURE 3. Lithological cross-section of the annalyzed zone; location on Figure 1; explanations as on Figure 2

represented by sand with gravel (Figs 2, 3). Admixture of larger fragments may suggest their formation under varying conditions of the river regime what is characteristic for the periglacial zone, during Warta Glaciation stadial [Bugo-Narew stadial according to Sarnacka (1974)]. Above them there is a layer of medium and fine sand which can be associated with the last glaciation period (Vistulian). There are fluvial sands transformed after deposition superficially by aeolian processes. Another series of sediments are mineral deposits (medium and fine sand) and organic ones (silts and sands of humus) related to the rain ablation processes and deposition of episodical river channels. They often fill deflationnary depressions. Surface sediments at the bottom of the Mała River valley are mainly sands, peats and silts.

The youngest part of the geological structure of the study area are anthropogenic embankments. These are sandy embankments of unpaved roads and pond dikes, as well as uncontrolled earthworks covering the central part of the analyzed area (Figs 3, 4). These embankments are built from clay sands, sandy clays and occasionally loams and sands of different grain. Post-peat exploitation excavation is filled with earthworks. These filling soils often contain significant admixture of humic substances and anthropogenic soils with debris. The earthworks and embankments are characterized by the horizontal variability and irregular, uncontrolled stratification.

All of the deposites mentioned earlier are accumulated over the top of the glaciolacustrine, cohesive deposits and they create one differentiated aqufier. The highest variation of the groundwater table depth was observed in the piezometer installed on the Pleistocene fluvioglacial plain and equaled $0.49 \mathrm{~m}$. The smallest variation of the depth to groundwater table was found in the vicinity of the Mała River channel and was around $0.03 \mathrm{~m}$. This can be explained by a high retention of the valley filled up with organic deposits (mainly peat). The value of hydraulic conductivity (estimated from the grain-size distribution curves) of the fluvial deposits which formed Pleistocene glaciofluvial accumulation level has 
range from $2.24 \cdot 10^{-5}$ up to $6.97 \cdot 10^{-5} \mathrm{~m} / \mathrm{s}$ for fine sands and from $1.48 \cdot 10^{-4}$ up to $1.8 \cdot 10^{-4} \mathrm{~m} / \mathrm{s}$ for medium sands. Within the series of permeable sediments there are intercalations of poor permeability organic layers. The channel of Mała River within the research area reveals a drainage nature. The lack of insulation in the first aquifer causes high vulnerability of groundwaters as well as river waters for the contamination. According to archival data (Miankowski 1997), the quality of the water of the Mała River is under an acceptable level. Chemical analyzes reveal high concentration of phosphate, BOD5, dissolved oxygen and Escherichia coli. Earthwork which filled up the peat excavation is also the reservoir of rainwaters, which in apart of freezing period saturate this differentiated structure. The earthwork could be also hazardous for the water quality because of unknown origin of the soils of this structure.

\section{The construction of a mathematical model of the hydrogeological conditions}

The model of the hydrogeological system is a result of archival materials analysis, field investigations and laboratory tests. The principal purpose of modelling was to define an optimal drainage system that will reduce the impact of the earthwork. Determining the qualitive change of groundwater table in the study area was the expected result of modelling.

The first step was to establish the currently existing geological and hydrogeological conditions in the model. The Visual MODFLOW is considered as the apropriate tool for the simulation of steady state and transient groundwater flow conditions occurring in the complexes consisting of one or multiple aquifers also hydraulically connected by direct or indirect contact, through the layers of separation (Małecki et al. 2006). The Visual MODFLOW is applicable for the estimation of the groundwater flow in polygenic valleys (Batelaan and Kuntohadi 2002, Brandyk 2011). The program solves the problem of groundwater flow using the finite difference method using iteration. Implementation of the numerical model requires the transcribe of differential equations for each point of the discrete space for each time step (McDonald and Harbaugh 1988).

Following assumptions have been made in the model for described hydrogeological conditions: (I) transient flow is modeled, (II) the infiltration recharge changes in time, (III) the hydraulic conductivity is stable in time, (IV) distribution of the spatial parameters and unhomogenity of the layers are demonstrated through diversification of parameters within the discretization framework.

Projection of the conceptual model in the horizontal plane (XY) was performed using an irregular rectangular grid. Digitizing grid for the research model consists of 113 columns and 100 rows. Model of the research area was projected in the local coordinate system (PUWG 1992). Digitizing of space by the vertical axis is usually in order to take into account the heterogeneity of the aquifer, through its division into sub-layers with different parameters of filtration. In the case of the modeled area six-layer diagram has been applied. The level of the top of the first layer is equal to the ground level. 
Elevation data necessary for modelling was acquired from the GIS resources of the CODGiK (Centre for Documentation of Geodesy and Cartography) in the form of DEM (digital elevation model). The morphology of the research area that existed before the construction of the earthwork has been reconstructed on the basis of the DEM data. These were used when type III condition in DRAIN variant was applied during the simulation of conditions within non-existent drainage ditches before the construction of the earthwork. The top of the other layers was projected in the model according to the geological cross-sections. All layers in the model (except for surface topography), have been limited by parallel planes on the top and at the bottom, respectively. The natural conditions were calculated on the way of diversification of the filtration coefficients in the all layers. Laboratory tests were used to calculate the filtration parameters.

While modelling of groundwater flow in terms of unknown filtration it is necessary to solve the system of differential equations. The equations are based on the defining of the boundary conditions and the initial conditions. These conditions provide the possibility to set the relation between the study area and the surrounding environment. Proper identification of the boundary conditions is one of the key elements needed to obtain reliable results of the study (Dąbrowski et al. 2010). The natural hydrodynamic boundaries of the study area and its hydrodynamic relation with the adjacent area were projected in the model by boundary conditions. The groundwater flow model uses three types of boundary conditions: type I - Specified Head, type
II - Specified Flow, type III - Head-dependent flow. All of these boundary conditions were used for the modelling of the study area.

The boundary conditions were defined according to a map of hydroisohypses as the result of hydrogeological analysis and field investigations including groundwater and water table measurements performed from April to June 2012. The Mała River channel creates the main groundwater drainage base within the study area, therefore the drainage follows to the West. It was assumed, that Mała River valley has water stagnation zones because it is a polygenic landform of melt-out, as well as deflation origin. Lateral supply from the southern direction can be disregarded in the model, because of the geomorphological features of Mała River channel as well as hydrogeological conclusions drawn from the geological cross-sections and the map of hydroisohypses. These results of our study indicate very low supply from the South. Supply from the eastern dominates, in particular from the wathershed (drainage divide) towards to the Mała River channel. The eastern limit of the study area is located inside the watershed (drainage divide) zone. Due to lack of water table measurements in this part of the catchment, type I condition in version Constant Head was used on existed reservoirs (which have good hydraulic connections with groundwater layer). The medium-grained sand occurs at the bottom of these water basins. Type III condition of River kind was used due to colmatation of riverbed. This condition was applied in first two layers that have contact with the river waters. The permeability parameter was estimated 
according to sequential approximation method during the calibration of the model. The system of drainage ditches was simlutaed by using a type III condition in the Drain kind. It is assumed that the drains remove water from the the Piaseczno weather station) and mean effective infiltration value [data derived from Pazdro and Kozerski (1990)]. All the boundary conditions that were used in the model are shown in Figure 4.

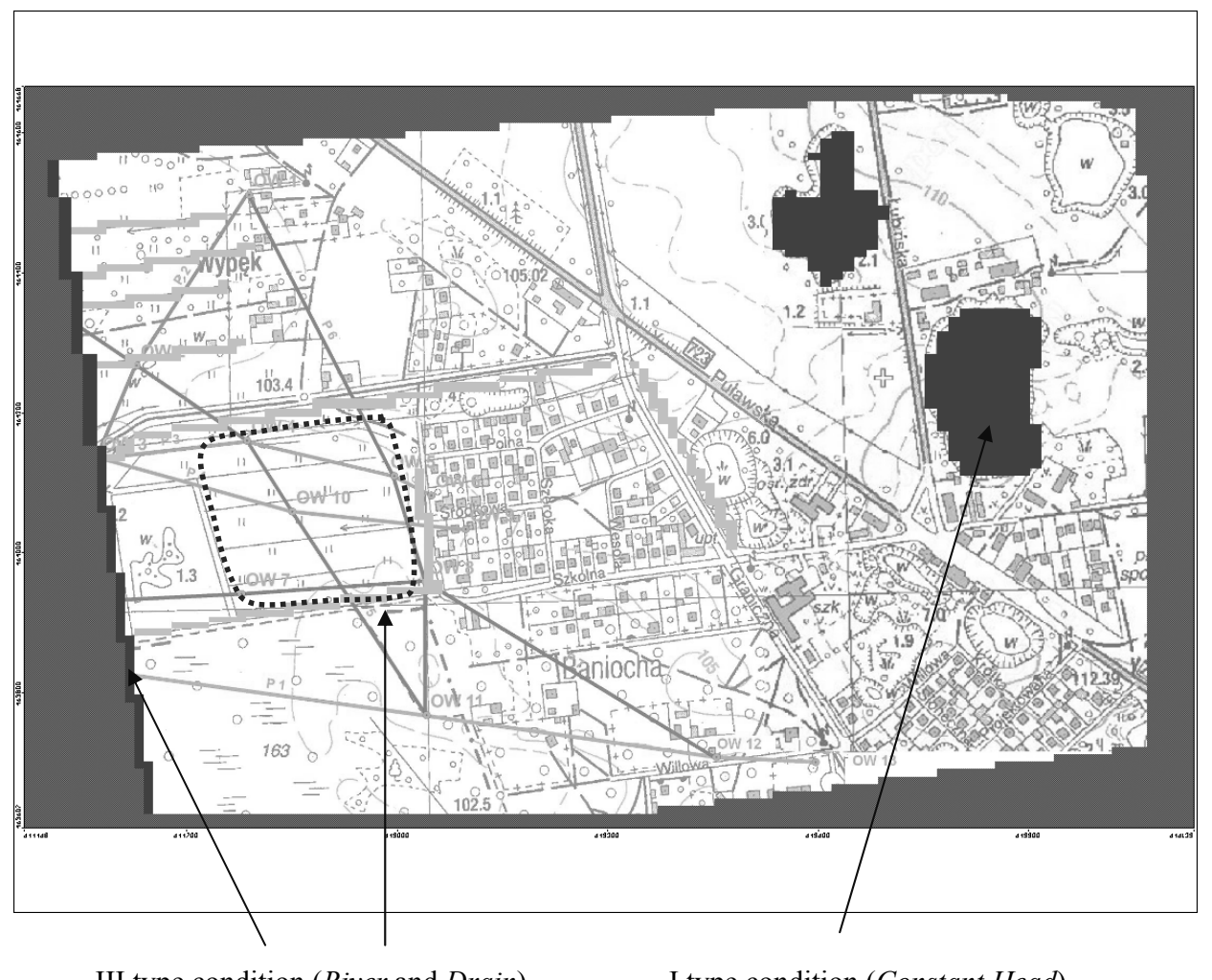

III type condition (River and Drain)

I type condition (Constant Head)

FIGURE 4. Boundary conditions used in the model; dotted line shows outline of the earthwork

aquifer with the expense proportional to the difference of pressure between the drain and the aquifer. This process occurs only when the groundwater table is located above the drain. The drain is treated as a spring that can drain water from the aquifer, but in the opposite direction the flow does not occur. The infiltration recharge was calculated as relation between rainfall value (data derived from

\section{Current groundwater flow condition with the earthwork presence}

The identification of groundwater circulation system in the study area, including the conditions of supply and drainage flow and the flow balance, was made on the basis of the results obtained from the mathematical modelling of the groundwater filtration. 
Preparation of steady state and its calibration according to the values obtained from the monitoring of groundwater and surface water table was the first stage of modelling. Insertion of the seven piezometers to the model was achieved by using Head Observation package. The calibrations values are: standard bug of $0.112 \mathrm{~m}$ and normalized RMS $13.866 \%$. The authors evaluated them as acceptable in the calibrated model. The other calibration parameters are presented in Figure 5. great part of the area located easterly from the earthwork is drained - isoline $103 \mathrm{~m}$ a.s.1. (Fig. 6). The model, that was used in the study, was calibrated during the low water stage (May 2012). For this stage the other map of hydroisohypses has been constructed. It reveals predominantly westward direction of groundwater flow. The base of the drainage for the ground and surface water is the Mała River valley. Groundwater resources are mainly influenced by infiltration of rain

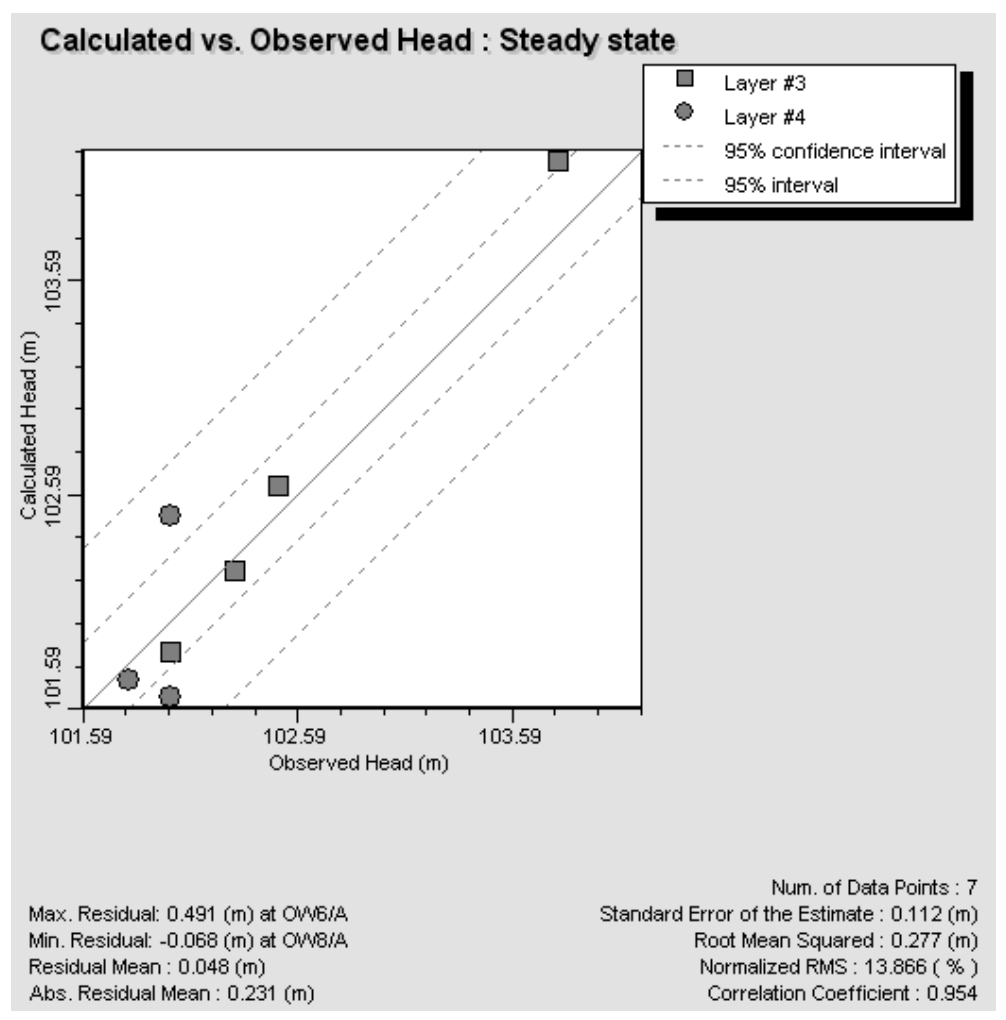

FIGURE 5. Calibration diagram

Impact of the earthwork and drainage ditches on the groundwater level is significant in the study area. One of the drainage ditches has been made along the northern boundary of the region. The water. However, the research was conducted during a dry period, while the groundwater level was stabilized on the depth of 1-2 $\mathrm{m}$ under the earth surface, and there was not risk of inundation. 


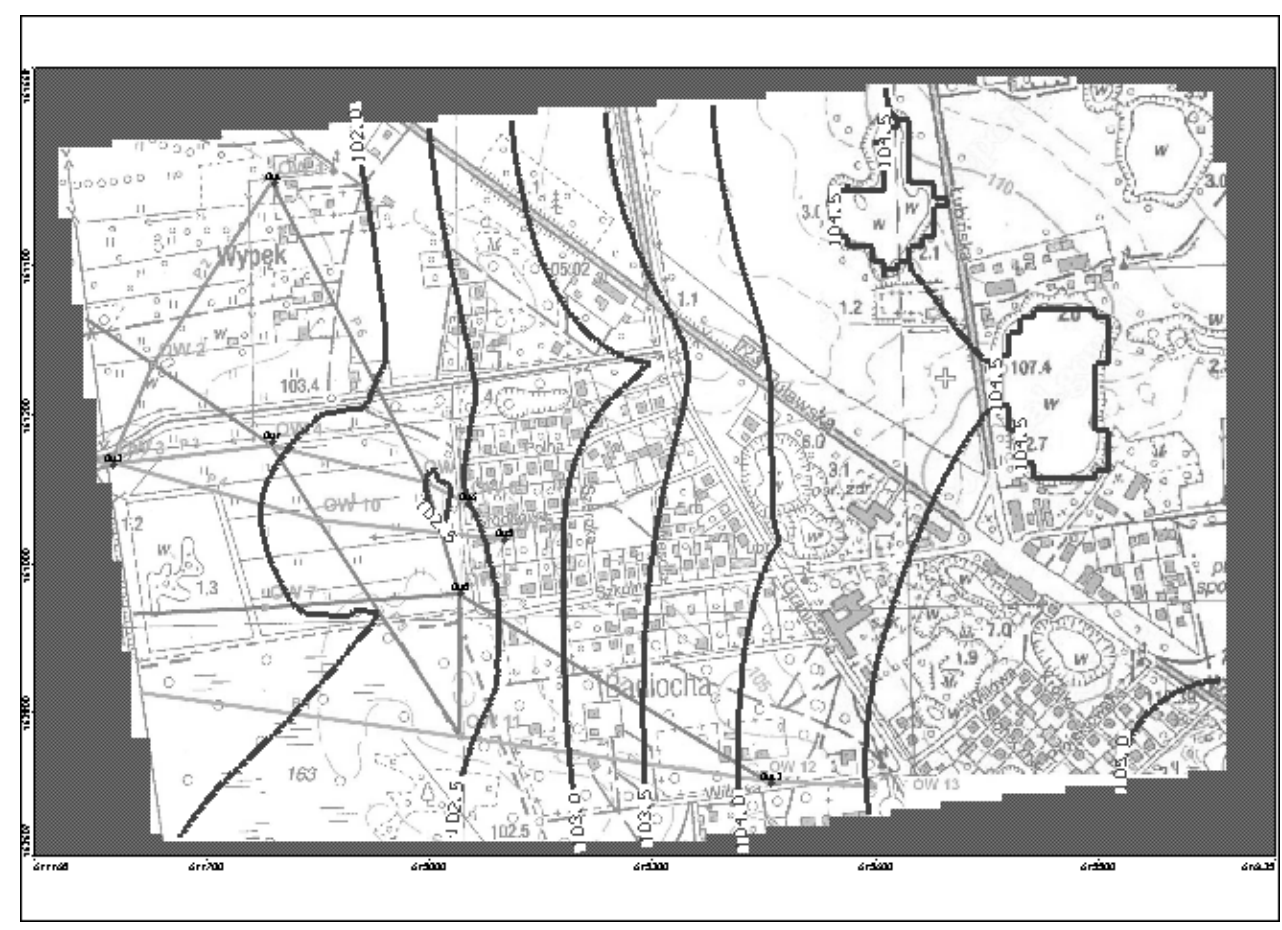

FIGURE 6. Map of hydroisohypses showing the conditions after the construction of the earthwork

Natural conditions, before the construction of the earthwork

Three-months transient flows simulations (90 steps) were conducted to imitate the response of the system to a heavy rainfall in conditions before the construction of the earthwork. Simulations were performed by gradual increasing of water supply within the range between "initial value" and "maximal effective infiltration" for established geomorphological condidions.

Natural groundwater conditions were reconstructed basing on the model without existing earthwork (Fig. 7). Before the construction, westward direction of groundwater flow occurred. The drainage ditches, constructed 50 years ago to decrease the groundwater level, had a great impact on the hydrogeological conditions in the study area. The resulting map of the modelling shows scope of the drainage. Southern part of the study area, that was not covered by a drainage system, is affected mostly by the lower groundwater level than in the rest of the region (Fig. 7).

\section{Simulation of the aquifer system response to planned engineering works}

Basing on the hydrodynamic model, we can conduct multivariate simulations of aqufier response to the engineering works. The greatest risk of inundation occurs in the eastern part of the study area. To avoid that it is necessary to redesign water table slopes and dredge 


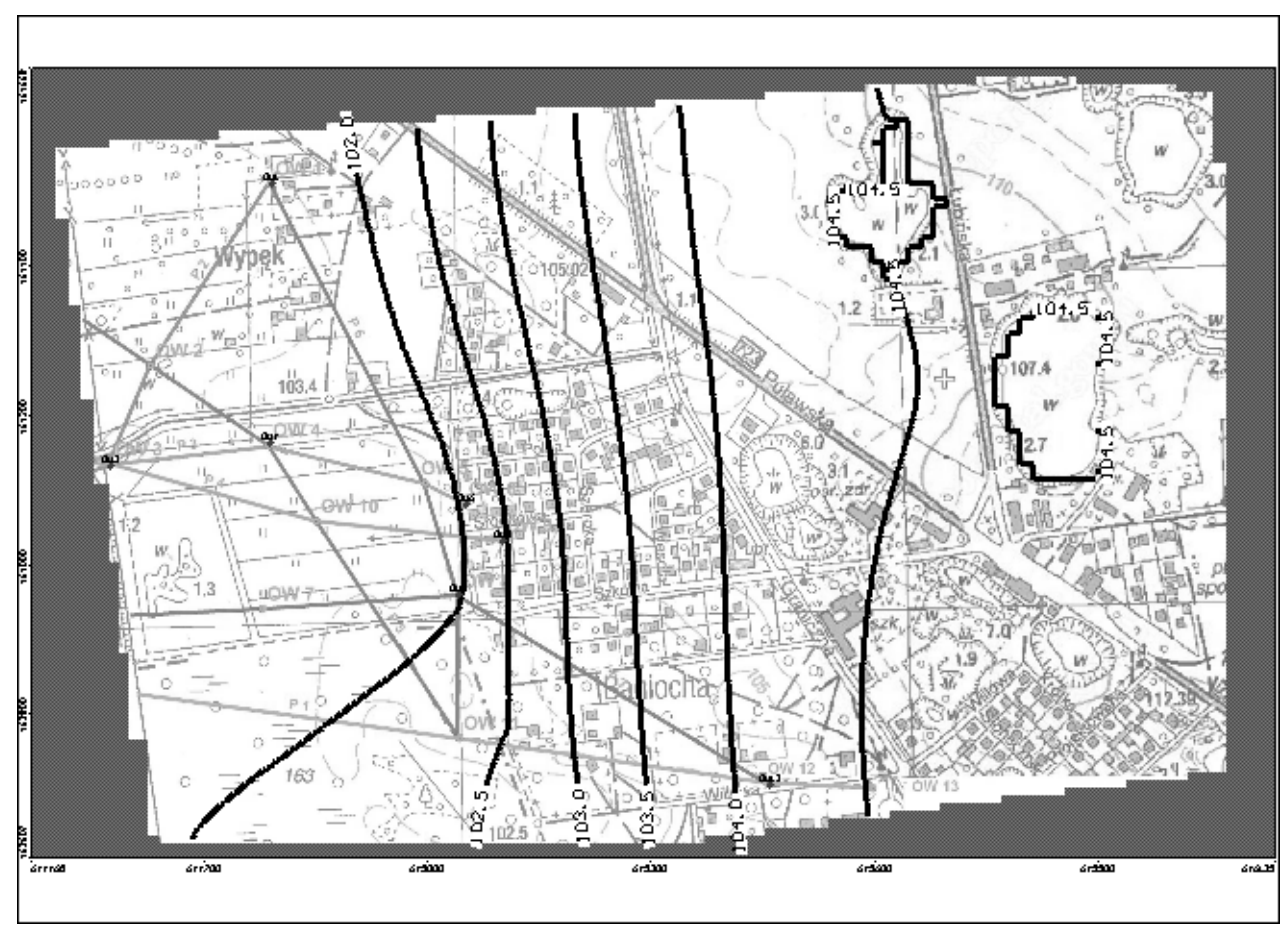

FIGURE 7. Piezometric contours map showing the condition before the construction of the earthwork

the drainage ditch located between the earthwork and the endangered buildings. This works should facilitate the drainage of groundwater in the study area and isolate the earthworks from private properties located in the eastern part of the study area. In order to restore the hydrogeological conditions is necessary to carry out a series of drainage works that will improve the drainage of the river valley bottom. The beginning of the ditch should be at equal level to the ground level that existed before the construction of the earthwork. Currently trench drains water into the Mała River channel and its channel slope is 0.024 (the length of the ditch is $463 \mathrm{~m}$ ). Deepening the ditch, at the expense of reducing the channel slope, will increase the efficiency of the drainage of the earth- work and the areas located easterly of it. The drainage ditch should be constructed along the entire length of the earthwork, and not just part of it, as is the case now. It is also necessary to ensure drainage of water from the ditch to the Mała River channel. Drainage ditch located in the southern part of the study area (along the boundary with the forest) discharges water to the pond. The pond has not a hydraulic contact with the river. To improve the operation of drainage systems it is essential to also dredge the reach of the Mała River channel located southerly from the study area. Dredging the river channel will reduce the resistance to flow and decrease the water stage in the channel. Outlets of the ditches to the river channel should be protected from possible backflow during a high water 


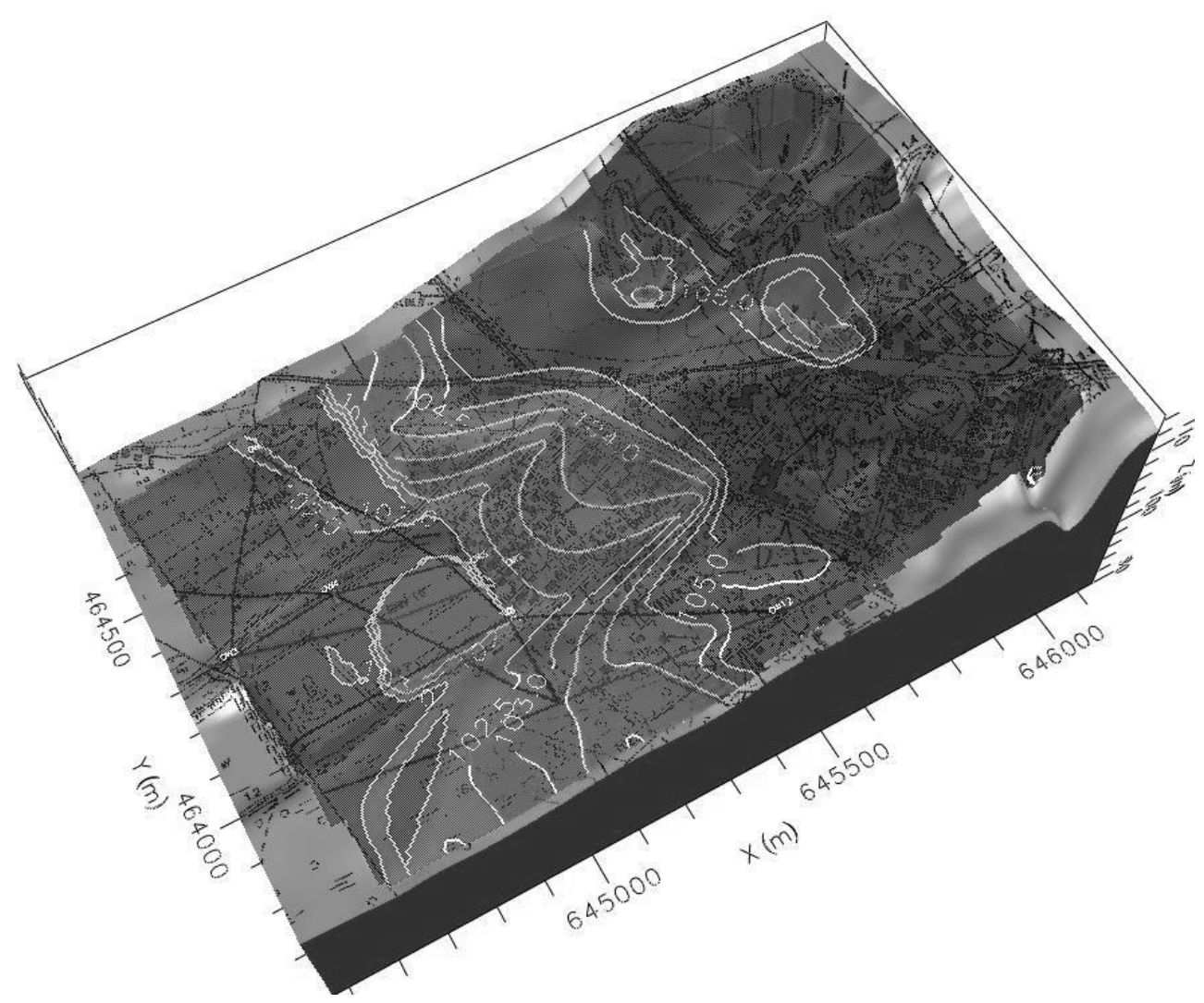

FIGURE 8. The surface of piezometric pressure affected by heavy rainfall (duration of 30 days) in the condition after the improvement of the draining system

stage. Reaction of the hydrogeological system on the drainage works is shown on the Figure 8. Our study shows that the proposed work may affect the decreasing of groundwater level about 1 up to $1.5 \mathrm{~m}$ in the eastern part of the study area back to the previous (before the earthwork construction) conditions.

\section{CONCLUSIONS}

The study area is located on the Pleistocene glaciofluvial plain and in the river valley that is polygenic, peated and human impacted, on the area that determines the small hydraulic gradient of the groundwater level. Polygenesis of the valley (the reach of present day Holocene river valley is located within the Pleistocene concave melt-out depression, created during aerial deglaciation of older ice sheet and modified in periglacial zone of the ice sheet during the last glaciation) determines the high retention of the valley, as manifested by slight variations in the level of groundwater.

Implementation of the earthwork in the middle part of the study area resulted 
in changes in groundwater flow regime, in particular, changes in flow directions within the slope of the valley, as well as, in raising the level of the groundwater table in the south-western part of the upland, causing local inundation.

The Visual MODFLOW enables modelling of hydrogeological dynamics of the study area in different conditions: (1) natural condition in the past; (2) in present condition including human impact; and (3) in future condition including improvement of draining system. Numerical modelling therefore is a suitable tool for finding out the best concept of restoration.

Intentional simplification of the model conditions, especially boundary conditions, included consideration of geomorphological aspect of the valley polygenesis and its hydrogeological conclusions. This way of the model construction was not as precise as regular hydrodynamic analysis, based on the long-term hydrogeological as well as hydrological studies. However, it proved to be sufficient for the purpose of reclamation way (drainage revitalization works) selection.

\section{REFERENCES}

BATELAAN O., KUNTOHADIT. 2002: Development and application of a groundwater model for the Upper Biebrza River basin. Ann. Warsaw Agricult. Univ. - SGGW, Land Reclam. 33: 57-69.

BRANDYK A. 2011: Ground water fed system restoration on the area of Przemkowsko-Przecławskie Wetlands. Ann. Warsaw Univ. of Life Sci. - SGGW, Land Reclam. 43 (1): 13-23.
BRANDYK T. 1990: Podstawy regulowania uwilgotnienia gleb dolinowych. Wyd. SGGW-AR, Warszawa: 1-120.

CHURSKI Z. 1993: Rozmieszczenie jezior i obszarów podmokłych. In: I. Dynowska. (Ed.). Przemiany stosunków wodnych w Polsce w wyniku procesów naturalnych i antropogenicznych. UJ, Kraków: 70-77

DABROWSKI S., KAPUŚCIŃSKI J., NOWICKI K., PRZYBYŁEK J., SZCZEPAŃSKI A. 2010: Metodyka modelowania matematycznego $\mathrm{W}$ badaniach i obliczeniach hydrogeologicznych - poradnik. Ministerstwo Środowiska, Poznań: 1-306.

LINDNER L. 1988: Zarys stratygrafii plejstocenu rejonu Białej Podlaskiej, wraz z próba korelacji z przyległymi obszarami Związku Radzieckiego. Przegląd Geologiczny 11: 637-647.

MAŁECKI J., NAWALNY M., WITCZAK S., GRUSZCZYŃSKI T. 2006: Wyznaczanie parametrów migracji zanieczyszczeń w ośrodku porowatym dla potrzeb badań hydrogeologicznych i ochrony środowiska. Wyd. Wydz. Geol. UW, Warszawa: 1-249.

McDONALD M.G., HARBAUGH A.W. 1988: A modular three-dimensional finite-difference groundwater flow model. Techniques of Water-Resources Investigation of the USGS 06-A1. U.S. Geological Survey, Washington: 1-586.

MIANKOWSKI Z., 1997: Mapa hydrogeologiczna Polski w skali 1:50 000, ark. Piaseczno. Państw. Inst. Geol., Warszawa.

OKRUSZKO H., PIÓRKOWSKI H., RYCHARSKI M. 1996: Charakterystyka mokradeł i użytków zielonych na tle zróżnicowania geograficznego kraju. In: Charakterystyka mokradeł i użytków zielonych $\mathrm{w}$ Polsce $\mathrm{w}$ aspekcie ochrony środowiska przyrodniczego. IMUZ. Falenty, manuscript.

PAZDRO Z., KOZERSKI H. 1990: Hydrogeologia ogólna. Wyd. Geol., Warszawa: $1-623$. 
SARNACKA Z. 1974: Szczegółowa mapa geologiczna Polski w skali 1:50 000, ark. Piaseczno. Wyd. Geol. Warszawa.

Streszczenie: Zastosowanie modelowania hydrodynamicznego do określenia wptywu zagospodarowania strefy brzeżnej poligenicznej doliny rzecznej na reżim hydrogeologiczny. Teren badań znajduje się w południowej części aglomeracji warszawskiej (miejscowość Baniocha w powiecie piaseczyńskim) i od północy przylega do Chojnowskiego Parku Krajobrazowego. Celem artykułu jest określenie wpływu rozbudowy osiedla mieszkaniowego na dynamikę wód podziemnych w mokradłowym obszarze o niekorzystnych warunkach geologiczno-inżynierskich i jego sąsiedztwie. Pod względem geomorfologicznym teren ten jest położony na pograniczu małej doliny rzecznej wypełnionej torfami oraz niższego poziomu plejstoceńskiej równiny sandrowej. Torfy wypełniające dolinę rzeczną w związku z rozbudową osiedla mieszkaniowego zostały wykopane i zastąpione niekontrolowanymi nasypami co doprowadziło do okresowego podtapiania budynków położonych na równinie sandrowej. Badania składały się z prac terenowych (wiercenia geologiczne, instalacja piezometrów, obserwacje wahania zwierciadła wód podziemnych, pomiary geodezyjne), laboratoryjnych (sitowa analiza granulometryczna osadów pobranych z otworów wiertniczych) i modelowania hydrodynamicznego (Visual MODFLOW w wersji 2009.1). Model hydrogeologiczny stał się podstawą do opracowania koncepcji renaturyzacji i poprawy stosunków wodnych w analizowanym terenie.

Slowa kluczowe: torf, mokradła, odwodnienie, modelowanie hydrogeologiczne, wody podziemne

\section{MS. received in February 2014}

\section{Authors' addresses:}

Filip Bujakowski

Tomasz Falkowski

Grzegorz Wierzbicki

Szkoła Główna Gospodarstwa Wiejskiego

w Warszawie

Katedra Geoinżynierii

ul. Nowoursynowska 166, 02-787 Warszawa

Poland

e-mail: tomasz_falkowski@sggw.pl

filip_bujakowski@sggw.pl

grzegorz_wierzbicki@sggw.pl

Kornelia Żukowska

Uniwersytet Warszawski

Instytut Hydrogeologii i Geologii Inżynierskiej

ul. Żwirki i Wigury 93

02-089 Warszawa, Poland

e-mail: kornelia.zukowska@student.uw.edu.pl 